\title{
Bir Zâhidin Örnek Muhalefeti: Hasan Basrî
}

\section{Şevket KOTAN*}

\section{An Exemplary Opposition of a Pious: Hasan al-Basri}

Citation/@: Kotan, Şevket, (2018). An Exemplary Opposition of a Pious: Hasan al-Basri, Milel ve Nihal, 15 (2), 134-147.

Abstract: Hasan al-Basri is famous opponent individuality against Umayyad power. He was a member of scholarly and wisdom circle. Beside that, he has known as a dissident who heavily criticizes the false attitudes of Umayyad caliphs in early age. However, the opposition of Hasan al-Basri has not set off a discussion that let to disorder and hostility in society. On the contrary, his attitude is on evoking the political powers about right and truth that based on Quran and Sunnah. Because of that, Hasan al-Basri has warned the powerful people within common sense and maturity and has tried to expand the justice and tranquility on community base. In this aspect the dissident attitude of Hasan al-Basri is a manifest of Quranic decree that commands goodness and prohibits badness.

Keywords: Hasan al-Basri, opposition, Umayyads.

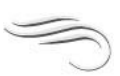

* Doç. Dr., İstanbul Üniversitesi, İlahiyat Fakültesi, Tefsir Anabilim Dalı [sevketkotan@yahoo.com]. 
Atıf/C: Kotan, Şevket, (2018). Bir Zâhidin Örnek Muhalefeti: Hasan Basrî, Milel ve Nihal, 15 (2), 134-147.

Öz: Hasan Basrî, Emevî iktidarına karşı muhalif tavrıyla öne çıkmış bir şahsiyettir. İlim ve irfan ehlinden olmasının yanı sıra özellikle ilk sıralardaki Emevî halifelerinin yanlış tutumlarını şiddetle eleştiren bir muhalif olarak bilinir. Ancak Hasan Basrî́nin muhalefeti, toplumda fitne çıkaracak bir tartışma ve düşmanlığı tetikleyecek bir tarzda değildir. Aksine Kur'an ve sünnet temelli hak ve hakikatin siyasi iktidarlara hatırlatılması ve toplumun bilinçli tutulmaya çalışılması şeklindedir. Bu nedenle Hasan Basrî sağduyu ve olgunluk içerisinde iktidar sahiplerine uyarılarda bulunmuş, adalet ve sükûnun toplum tabanına yayılması için gayret etmiştir. Bu yönüyle Hasan Basrî'nin muhalif tutumu, iyiliği emredip kötülükten nehyeden Kur'an emrinin bir tezahürü mahiyetindedir.

Anahtar Kelimeler: Hasan Basrî, muhalefet, Emeviler.

\section{Giriş}

Hasan Basrî (641-728), adeta Hz. Peygamber döneminden Emevîlerin hüküm sürdüğü saltanat zamanlarına kalmış bir sahabi gibidir. İmanı ve ihlasıyla şekillenen zahit kişiliği tarihte büyük bir etki bırakmış, dikkat çekici şahsiyeti birçok bakımdan araştırma konusu olmuştur. Hasan Basrî́nin, dikkat çekici özellikleri içerisinde en çok öne çıkan yönü, onun zahit kişiliğiyse de asıl ilginç yönü, onun muhalefet anlayışı ve bu anlayışın oturduğu felsefi zemindir. İncelendiğinde, dini/siyasi anlayışı ile bu anlayışın kelami temelleri ve zahidane yorumları arasındaki geçişlerin, şahsına münhasır bir karakter arz ettiği görülmektedir. Onun, dengeli, gerçekçi ve aynı zamanda sağlam dini temellere dayanan örnek bir muhalefet anlayışına tanık olmaktayız. Bu makalenin konusu da onun örnek muhalefet anlayışıdır. Bu anlayışı kavramak için muhalefetin gerekçesi, üslûbu, bu üslûbun felsefi temelleri ve sonuçları üzerinde durmak gerekir.

\section{Hilafet ve Meşruiyet}

Hasan Basrî́ye göre İslam hilafeti esasında meşveret temeline dayanmaktadır. Bu yüzden halife şûra ile seçilir. Nitekim ilk dört halife de bu yolla seçilmişlerdir. Ne var ki Muaviye ile birlikte meşru olan bu yol terk edilerek saltanata geçilmiştir. Bu nedenle Hasan Basrî, Emevi saltanatına temelden muhalifti. Çünkü o, bu sistemin dayandığı temeli İslam'a aykırı görerek reddediyordu. İşte muhalefetinin birinci gerekçesi olan bu durumdan dolayı, Muaviye'yi ve saltanatın diğer müsebbiblerini şiddetle eleştirmiştir. Ona göre Muaviye'de öyle kötü özellikler bir araya gelmiştir ki bunlardan sadece 
biri, bir insanı dini açıdan helake sürüklemeye yeterlidir. Bir kere o, sefihleri ümmetin başına bela etmiş ve böylece insanları birbirine düşürmüştür. Aynı zamanda emirliği meşveretsiz elde etmiş ve kendisinden sonra oğlu Yezid'i kendi eliyle devletin başına getirmiştir. Bundan başka aşağılık bir hayat yaşama yoluna gitmiş, $\mathrm{Hz}$. Ali'nin muhibbi olan Hucr b. Adiyy'i de günahına girerek katletmiştir."1

Hasan Basrî'nin nazarında, Muaviye dışında diğer müsebbibler ise, Amr b. As ve Muğire b. Şu'be'dir. Bu şahsiyetleri, İslamî yönetim sistemini bozarak saltanat yönetim tarzını İslam'a sokmakla suçlamakta ve saltanat sisteminin sorumluluğunu büyük bir günah olarak onlara yüklemektedir. O Amr b. As hakkında şunları söylemektedir: “Amr b. As, Sıffîn savaşında Muaviye'nin Hz. Ali'ye mağlup olacağı bir sırada şu hileye başvurmuştu: Askerlerinden her birine mızraklarının ucuna Kur'an sayfaları takmalarını emretmiş ve böylece karşı tarafa güya barış istediğini ima etmiştir. Hatta Hâricî fırkası onun bu hilesine kanmış, Kur'an'ın hakem tayin edilerek savaşın hemen sonlandırılmasını Hz. Ali'den istemiştir. İşte bu hakem meselesi, kıyamete kadar sürecek ihtilafın konularından birisi olmuştur. Hâlbuki Hz. Ali, Amr'ın bu hareketiyle ne kastettiğini anlamış ve "evet bu hak kelamıdır; fakat bununla batıl murad edilmektedir," diyerek işin iç yüzünü anlatmak istemiştir."2

Muğire b. Şu'be'ye gelince, o Kûfe valisi olduğu esnada, Muaviye kendisine bir mektup yazmış, azledildiğini bildirerek derhal Şam'a dönmesini istemişti. Fakat Muğire bu emri dinlemeyerek uzun bir müddet sonra ancak halifenin huzuruna çıkmıştı. Muaviye onun bu kadar gecikmesine hiddetlenerek, "neden bu kadar geç kaldın?" diye çıkışmıştı. Bunun üzerine Muğire, "efendim, başladı̆̆ım bir iş vardı onu yarım bırakıp dönmeyi uygun görmedim," demişti. Muaviye söz konusu işin ne olduğunu sorunca, Muğire, "oğlun Yezîd için Kûfelilerden biat aldım” cevabını vermişti. Bunun üzerine halife, Muğire'ye dönerek, doğru mu söylüyorsun, bunu gerçekten yaptın mı?" diye sorunca vali, "evet yaptım, cevabını vermişti. Bunun üzerine Muaviye şunları söyledi: "haydi git, başladığın işi tamamla." Muğire'nin bu yaptığıyla Kûfeliler Muaviye'nin oğullarına biat ettiler. İşte bunun sonucunda hilafette saltanat usûlü

1 Ebu Ca'fer Muhammed b. Cerir et-Taberî, Tarihu'l-Ümem ve'l-Mülûk, Daru'l-Fikr, Beyrut, 1987, s. 196.

2 Cemaleddin Ebu'l-Ferec İbnu'l-Cevzî, Adab-u Hasanu'l-Basrî, Beyrut, 2008, s. 63. 
ihdas edilmiş oldu. Eğer tevarüs usûlü ortaya çıkmasaydı, kıyamete kadar halife şûra tarafından tensip edilecek ve böylece bu makama, takva ve faziletinde ittifak edilmiş bu işe ehil ve iman sahibi kimseler getirilecekti."3

Söz konusu şahsiyetlerin, Hz. Peygamber'in sünnetine aykırı olan bir uygulamayı başlatmaları hasebiyle büyük bir günah işlediklerine inanan Hasan Basrî, bu haksızlığı açık şekilde kıyasıya eleştirmiş, kınamıştır. $\mathrm{O}$, onlar hakkında konuşmakta bir vebal da olmadığını düşünmekteydi. Çünkü ona göre şu üç sınıf insan hakkında konuşmak gıybet değildir: (i) Fıskını açıkça ilan edip fıskı ile anılan fasık; (ii) Bid'atleri ile anılan bid'at sahibi kişi; (iii) Zulümle anılan zalim (câir) hükümdar. ${ }^{4} \mathrm{O}$ da devrindeki cari haksızlıkları dile getirirken doğal olarak zulmedenleri anıyordu. Ki bunlar, halifenin seçimi hususunda saltanat bid'atini ihdas etmişlerdi.

Hasan Basrî́nin bu düşüncesinin Kur'an ve sünnetteki dayanağını da tefsirinde görmekteyiz. Nisa suresi 58. ayette geçen “emanetleri ehline verin" ayeti ile ilgili olarak, ayetin genel olarak vedia ve diğer emanetler hakkında nazil olduğunu söyledikten sonra, Hz. Peygamber'in "emaneti güven verene ve ihanet etmeyene teslim ediniz," mealindeki hadisini zikretmektedir. Nisa suresi 59. ayette de geçen "emir sahiplerine itaati" emreden ayetin tefsirinde de, emir sahiplerini âlimler olarak açıkladıktan sonra, Hz. Peygamber'den gelen "Halîk'e isyan konusunda mahlûkata itaat yoktur," hadisini zikretmektedir. ${ }^{5}$

Hasan Basrî́nin Emevî saltanatına muhalefet etmesinin diğer bir gerekçesi ise, yöneticilerin adil olmamaları ve halka zulüm etmeleridir. Muaviye zamanından itibaren halk zulme maruz kalmaya başlamış ve bu zulümler Yusuf b. Haccac'in uygulamalarıyla da devam etmiştir. Hucr b. Adiyy'in katli hadisesinde görüldüğü gibi, bazı muhalifler haksız yere katledilmişlerdir. Nitekim o, daha sonra temas edileceği gibi, Haccac'1 zorba olarak tavsif etmiştir.

3 İbnu'l-Cevzî, Adab-u Hasanu'l-Basrî, s. 63.

4 İbnu'l-Cevzî, Adab-u Hasanu'l-Basrî, s. 61.

5 Tefsir-u Hasan Basri, (Muhammed Abdurrahim neşri) Kahire, 1992, c. i, ss. 285286. 


\section{Kader Hakkında Tartışmalar}

Hasan Basrî́nin Emevi iktidarını şiddetle tenkit etmesinin nedenlerinden bir diğeri de yönetici tabakanın kendi yaptıklarının insanların kaderi olduğunu söylemeleridir. Böylece onlar, itiraza neden olan olumsuz politikalarını ilahî takdire dayandırarak zulme varan uygulamalarının sorgulanmaması için kader inancına dayanan bir kalkan oluşturmakta, kendilerine de sorgulanamaz ve manevi bir mertebe ihdas etmekteydiler. Hâlbuki birazdan kaderle ilgili görüşlerine değinilirken ifade edileceği gibi, Hasan Basrî böyle bir kader anlayışını batıl olarak addetmekteydi. Batıl uygulamalarına kaderden bir kalkan oluşturanları Allah düşmanı diye niteleyerek bu iddia sahiplerine "Allah'ın düşmanları yalan söylüyorlar" diyerek karşı çıkmıştır. ${ }^{6}$ Batıl olarak gördüğü bu anlayışı yıkmak adına olmalı ki Hasan Basrî, Emevi sultanları tarafından adeta resmi kader görüşü haline getirilmek istenen cebr temelindeki kader görüşünü de şiddetle tenkid etmekteydi. Ona göre cebrî kader görüşü Kur'an'a aykırı idi. Nitekim onun insan iradesini yok sayan bu kader görüşünü tenkid için söyledikleri halife Abdülmelik b. Mervan'ın kulağına gelince, halife bundan rahatsız olarak Hasan Basrî’ye aşağıdaki mektubu göndermişti:

Emirü'l-mü'minin Abdülmelik b. Mervan'dan Hasan Basrî'ye: Sana selam olsun, zatından başka ilah olmayan tanrıya hamdüsena ederim. Daha önce geçen âlimlerden hiç birinde duyulmamış, bir tarzda kader meselesini izah etmekte olduğun Emirü'l- mü'minîn'e ulaştı; Emirü'l-mü'minîn, zamanına kadar yaşayan sahabeden hiç birinin bu konuyu senin izah ettiğin gibi anladığını ve hakkında fikir yürüttüğünü bilmiyordu; hâlbuki senin salahî halini, dinindeki faziletini, ilme karşı olan anlayış, istek ve titizliğini biliyordu; bütün bunlardan sonra, Emir'l-mü'minîn senden nakledilen bu sözü beğenmedi. Bu meseledeki fikrini ona yaz. Bu iddiada nereye dayanıyorsun? Resulullah'ın ashabından birinin rivayetine mi, yoksa kendi fikrine mi, yahutta Kur'an'in tasdik ettiği bir hükme mi? Biz bu mesele hakkında senden önce münakaşa etmiş, veya söz söylemiş, bir kimse işitmedik, bu

6 İbn Kuteybe, el-Mearif, tahk., Servet Ukkașe, Daru'l-Mearif, Mısır, 1969, s. 441. 
husustaki görüşünü Emiru'l-mü'minîn'e bildir ve açıla. Allah'ın selam, rahmet ve iyiliği sana olsun. ${ }^{7}$

Hasan Basrî, Abdülmelik b. Mervan'ın bu mektubuna karşılık uzun sayılabilecek bir mektup göndererek halifenin sorusunu cevaplamaya çalışmış, kader konusundaki düşüncelerini dayanaklariyla birlikte ortaya koymuştur. Tamamı Kur'an ayetlerine dayanan ve Kur'an'ın Kur'an'la tefsirinin de iyi bir örneği mahiyetindeki bu risalede Hasan Basrî insanın kaderini, irade hürriyeti ve insanın yaptıklarından sorumluluğu temelinde ele almakta, insan fiillerinin ilahi takdirle meydana geldiği inancının temelsizliğini ortaya koymaktadır. Ona göre Allah kulların fiillerini takdir etmemiştir. Eğer böyle olmuş, olsaydı "dilediğinizi işleyin" (Fussilet, 40) yerine, "Üzerinize takdir ettiklerimi işleyin," derdi. Yine "dileyen inansın dileyen inkâr etsin,"(Kehf, 29) demeyip bunun yerine, "İstediğim kimse iman etsin, istediğim de kâfir olsun," derdi. Allah Ademoğlu tabiatına ilhamla iyiliği kötülükten ayırma özelliğini verdiğine göre, insan fiillerinde kudret sahibidir. Allah sadece yol göstermektedir, kulların fiillerine karışmamaktadır. Allah, kullara, yapılacak işleri mukadder kılmamıştır; fakat şöyle yaparsanız size böyle yaparım, böyle yaparsanız size şöyle yaparım, demiştir."

Hasan Basrî́ye göre, Kur'an'ın bazı ayetlerine kaderci bir açıklama tarzının hâkim olması, kaderci bir anlayışa sahip olan Arapların dili olan Arapçaya dayanmaktadır. Ona göre "Allah, Arapların aşina oldukları dille konuşuyor. Mesela, bir Arap şairi şöyle söylemiştir:

Zamanın harap etmesi için bina yapılması gibi / Anneler de yavrularını ölüm için besler.

Burada şair, çocukların sonunun ölüm, binaların sonunun da harabiyet olduğunu bildiriyor. Hâlbuki yavrular ölüm için değil, beka için beslenirler; meskenler de harap olmaları için değil, mamur kalmaları için yapılırlar. Ey Emire'l-müminîn! Kur'an da Arapça bir

7 Bk. "Hasan Basrî́nin Kader Hakkında Halife Abdülmelik Bin Mervan'a Mektubu", çev.: Lütfi Doğan, Yaşar Kutluay, Ankara Üniversitesi İlahiyat Fakültesi Dergisi, c. iii, sayı iii, 1954.

8 "Hasan Basrî̀nin Kader Hakkında Halife Abdülmelik b. Mervan'a Mektubu”, s. 76. 
kitaptır ve Allah onu Araplara kendilerinin bildikleri dille indirerek, onlara alışık oldukları bir dille hitap etmiştir. ${ }^{9}$

İlim ehlini hakkın izharı ve onu ikame etme konusunda sorumlu olarak görmesi de Hasan Basrî'nin Emevi iktidarına muhalefetinin diğer bir gerekçesini oluşturmaktaydı. Ona göre yüce Allah, insanlardan hiç bir şeyi gizlememek, bildiklerini onlara anlatmak konusunda âlimlerden söz almıştır."10 Âlimler hakkın temsilcileri makamında durarak onun gereğini hakkıyla yerine getirmelidirler. $\mathrm{O}$, bu düşüncesine hayatında kuvvetle bağlı olarak kalmış, bir taraftan her gayr-i meşru duruma muhalefet ederek eleştirip halkı bilinçlendirirken, diğer taraftan da uygun gördüğ̈̈ âlim tipine yakışır vakarı ile uygulamalarını tasvip etmediği idareden uzak durmuştur. Zira ilim ehlinin asli vazifesi, öncelikle halka nasihat ile onların ıslahına çalışmaktır. Nitekim Hasan Basrî, bir seferinde zalim diye tanımladığı Haccac b. Yusuf'un kapısında onunla görüşebilmek için bekleşen bazı âlimleri görünce onları tenkit ederek şöyle söylemiştir:

Sizi buraya getiren şey nedir? Allah teâla sizin gibi hükümdar kapısında bekleyen âlimleri çoğaltmasın. Sizler dünyalık peşinde koşan şu hükümdarın huzuruna mı girmek istiyorsunuz? Allah'a yemin olsun ki, onlarla bir araya gelerek yakınlaşmak iyilerle beraber olmaya benzemez. Onların meclisleri salihlerin meclisi gibi değildir. Hadi burayı terk edin, onlardan ayrı durun ki Allah ta sizin ruhlarınızı ve cesetlerinizi ayrı tutsun. Allah teâla iman edenlerden sizin şu halinizdekileri çoğaltmasın. Ayakkabılarınızı ve en güzel elbiselerinizi giymişsiniz. Saçlarınızı kesmiş, gözlerinize sürme çekmişsiniz. Şu halinizle sizler çok kötü bir cemaat olmuşsunuz. Tamahınızdan dolayı bıyıklarınızı bile kesmişsiniz. Böyle yaparak ulemayı rezil ettiniz. Allah ta kusurunuzu örtmesin. Vallahi eğer sizler yanınızdaki ile yetinip tenezzül ederek onlardaki servete göz dikmeseydiniz, onlar size yönelecek, sizdeki ilminize gipta edeceklerdi. Fakat siz mal ve servete tamah ettiniz. Bunun üzerine onlar ne size meylettiler,

9 “Hasan Basrî'nin Kader Hakkında Halife Mervan b. Hakem'e Mektubu”, ss. 8081.

10 İbnu'l-Cevzi, Adab-u Hasanu'l-Basrî, s. 108. 
ne de sahip olduğunuz ilme. Allah teâla kendisinden uzaklaşan kullarını rahmetinden işte böyle uzaklaştırır."11

Ona göre, ümmetin hep hayır üzere kalabilmesi için hayır ehli olan kimselerin şer ehli kimselerle arkadaş olmamaları, iyilerin fasıklara tazim etmemeleri ve âlimler ile kurranın devlet ricaline meyletmemesi gerekir.12

\section{İdarenin Temel Sorumluluğu}

Ne var ki Hasan Basrî, haksızlığa karşı çıkmak adına geliştirdiği muhalefet anlayışının gereklerini canı pahasına cesaretle yerine getirmesine rağmen, o dönemlerde böyle durumlarda çokça başvurulan ve hurûc (başkaldırı) diye bilinen isyan teşebbüslerine de onay vermemiştir. Hurûc hakkında görüşü alınmak istendiğinde o fikir beyanında bulunarak bu tür teşebbüslerden uzak durulmasını tavsiye etmiştir. $\mathrm{O}$ halde burada şu soruyu sormak gerekiyor: $\mathrm{O}$, dini ve ahlaki bakımdan sıkıca muhalifi olduğu bir idare şeklini ortadan kaldırıp meşru bir idare şekline geçmeyi hedefleyen başkaldırı teşebbüslerine niçin desteklemeyerek karşı durmuştur? Bu sorunun cevabına bakıldığında, onun bu bakış açısının da siyaset/hilafete ilişkin düşüncesine dayandığ 1 görülmektedir. Onun bu düşüncesine göre halifeler, asgari düzeydeki vazifelerini ifa ettikleri takdirde onlara karşı fiili bir kalkışma caiz değildir. Dolayısıyla o, Emevi hilafetini, bu bakımdan meşru bir hilafet olarak addetmiş, bu tür teşebbüslere cevaz vermemiştir.

Hasan Basrî́ye göre Emevi halifeleri, bir halifenin vazifesi olan görevleri yerine getirmektedirler. Çünkü onlar, halifelerin asli vazifeleri olan şu beş şeyi ifa ediyorlar: cuma, cemaat, fey' (vergi, zekat) sınır güvenliği ve hadlerin tatbiki. Her ne kadar adaletsiz davranıp zulmetseler de yine de onlar olmadan din yaşatılamaz. Nitekim onlar vasıtasıyla ıslah olanlar bozulanlardan daha fazladır." Ona göre idareciler olmasaydı halk birbirine zulmederdi. ${ }^{13} \mathrm{Bu}$ nedenle mevcut hailfeye itaat etmek meşru ve gereklidir.

$\mathrm{Bu}$ yaklaşımının daha temelinde ise, onun Hz. Peygamber'in bir hadisini zikrederek ifade ettiği devlet yönetimine dair görüşü yatmaktadır. Bir gün Haccac'a beddua eden bir adamı görünce,

\footnotetext{
11 İbnu'1-Cevzi, Adab-u Hasanu'l-Basrî, s. 107.

12 İbnu'l-Cevzî, Adab-u Hasanu'l-Basrî, s. 55.

13 İbnu'l-Cevzi, Adab-u Hasanu'l-Basrî, s. 58.
} 
"onun başa gelmesini sağlayan sizlersiniz ki başınıza geçirildi," dedikten sonra, "idarecileriniz sizin amelleriniz gibidirler. Layık olduğunuz şekilde idare edilirsiniz" hadisini zikretmiştir. Arkasından da ekleyerek, "adamın birisi bir gün salihlerden birine bir mektup göndererek idarecilerin zulmünden şikâyette bulunmuş. Bunun üzerine o salih zat adama mektup yazarak şöyle demiştir: 'Ey kardeşim! İdarecilerin baskıcı idaresinden dolayı içerisinde bulunduğunuz zulmü ifade eden mektubun bana ulaştı. Masiyet işleyen birinin işlediği günah sonucu maruz kalacağı zulümden şikâyet etme hakkı yoktur. Başınıza gelenin, sizin uğursuz günahlarınızın bir sonucundan başka bir şey olduğunu zannetmiyorum, vesselam'".14

Hasan Basrî́nin Emevi sultanlarına muhalefet etmesinin, dinî/ahlakî temeli dışında başka bir sebebinin olmadığını, onun Ömer b. Abdulaziz ile olan ilişkisinden anlamaktayız. Hasan Basrî̀nin nasihatlerine değer veren halife Ömer b. Abdulaziz bir mektupla kendisinden nasihat istemişti. Hasan Basrî'nin cevaben yazdığı mektubu okuyunca oldukça duygulanan halife gözyaşlarını tutamayarak ağlamış ve şöyle demişti:

Allah Hasan'a merhamet etsin. O her zaman bizi düşünür. Ne zaman bir tehlike ile karşılaşsak hemen bizi uyarır, bilmediğimiz konularda bize hep yardımcı olur. Allah için söylemeliyim ki o, nasihat edenlerin en şefkatlisi, vaaz edenlerin en fasih ve doğru söyleyenidir. ${ }^{15}$

Halife ile sıcak bir ilişkisi olduğu anlaşılan Hasan Basrî, adaletiyle tarihte "İkinci Ömer" olarak anılan halifeyi takdir etmekte, ona her daim yardımcı olmak için nasihat ile dua etmektedir. Hasan Basrî bir mektubunda Ömer bin Abdulaziz'e hilafet anlayışını da açılayan şu öğüdü vermektedir:

Ey Emire'l-mü'minîn! Allah'ın sana yönetimini emanet ettiği idaren altındaki insanların yönetimi konusunda şu köle gibi olmaktan sakın. Efendisi kölesine güvenerek korusun diye servetiyle çoluk çocuğunu ona emanet eder. Fakat köle efen-

14 İbnu'l-Cevzî, Adab-u Hasanu'l-Basrî, ss. 115-116.

15 İbnu'l-Cevzi, Adab-u Hasanu'l-Basrî, s. 123. 
disinin emanetine hıyanet ederek malını saçıp savurur. Çoluk çocuğuna sahip çıkmayarak onları mahrum bırakır, fakir düşürür. Mal ve servetini telef eder. ${ }^{16}$

Mülkü de halkı da Allah'ın emaneti olarak gören Hasan Basrî, Halifenin yaklaşım ve adil yönetimini gördükçe de ona dua etmiştir: "Halife hakka kail oldu, nasihatlerimizi dinledi. Allah onun saltanatıyla hayrı ve nimeti daim kılsın. Saltanatıyla ümmete rahmetini ihsan etsin. Hilafetini ümmet-i Muhammed'in hayrına bereketine vesile kilsin." 17

\section{Fitne Katilden Kötüdür}

Şahsiyeti İslam toplumunun büyük bunalımı esnasında olgunlaşmış olan Hasan Basrî için ümmetin birliği büyük önem arz etmektedir. Hz. Osman öldürüldüğünde on dört yaşında olan Hasan Basrî'nin bakış açısı, genelde ümmetin, özelde kendisinin iç dünyasında yaşadığı bu travmalarla şekillenmiş olmalıdır. M. Z. İşcan'nın da dikkat çektiği gibi, "onun ümmet için ortaya koyduğu çözüm, ümmetin birliği üzerine temellenmiştir. Ona göre birliğin en önemli yolu, adalet doğrultusunda nasihattir. Bu yüzden ne isyan ve silahlı mücadele ne de suskunluk yoluna başvurulmalıdır. Nitekim çevresindekiler; "ancak huruc etmek suretiyle değiştirebilirsin" dediklerinde o, 'Allah bir insanı huruçla değil, tevbe ile değiştirir' diye karşıllı vermiştir."18

Fitnenin bütün acısını derinden yaşamış olan Hasan Basrî’ye göre fitneyi uyandıracak durumlardan uzak durmak gerekir. Zaten ona göre fitne, taattan gafil olan kullarına Allah'ın bir cezasıdır. Nitekim o, fitnenin mahiyetini ve fitneye götüren sebepleri soran bir kişiye şu cevabı vermiştir: "Fitne, Yüce Allah'ın kullarına bir cezasıdır. İnsanlar ne zaman isyan eder taattan gafil olurlarsa o zaman Allah teâlâ fitneyi onlara ceza olarak verir."19

Hasan Basrî'nin hilafet anlayışının şekillenmesinde, onun hilafeti aklen vacip olarak görmesinin önemli bir etkisi olduğu söylenebilir. Fahreddin Razi; Câhız ve Ka'b ile birlikte Hasan Basrî'yi de bir

\footnotetext{
16 İbnu'l-Cevzi, Adab-u Hasanu'l-Basrî, ss. 111-112.

17 İbnu'l-Cevzî, Adab-u Hasanu'l-Basrî, s. 111.

18 Mehmet Zeki İşcan, "Ehl-i Sünnet'in Oluşumunda Öncü Şahsiyetler, Hasan Basrî ve Ebû Hanife Üzerine Bazı Mülahazalar",Komisyon, Tarihte ve Günümüzde Ehli Sünnet, İstanbul, 2006, s. 66.

19 İbnu'l-Cevzî, Adab-u Hasanu'l-Basrî, s. 59.
} 
devletin varlığının gerekliliğini sem'an değil, aklen vacip gören düşünürlerden saymaktadır. Nitekim Hasan Basrî'ye göre bir yöneticinin varlığını din değil akıl gerekli görür. ${ }^{20}$

Hasan Basrî, Emevi saltanatının şiddetli bir muhalifi olmasına ve bu muhalefetini gerek duruşu ve gerekse de konuşmalarıyla açık şekilde dışa vurmasına rağmen yöneticilerin şerrinden nasıl korunabildi? Kanaatimizce Hasan Basrî hakkında üzerinde durulacak en önemli noktalardan birisi burasıdır. Kuşkusuz ki bu meyanda geçerli birçok izahta bulunulabilir ancak burada önemli olan asıl nedeni tespit edebilmektir. Asıl sebep ne olabilir?

Hasan Basrî̀nin biyografisinin en ilginç taraflarından birisi, onun mü'minlerin annesi Hz. Ümmü Seleme'nin evinde büyümüş olmasıdır. Hasan, validemiz Ümmü Seleme'nin azatlısı olan annesi vesilesiyle Ümmü Seleme'nin evinde büyümüş ve yetişmesinde onun büyük etkisi olmuştur. Hatta rivayet edildiğine göre kendisi Ümmü Seleme tarafından çokça sevildiğinden dolayı validemiz ona sütünü de emzirmiş̧ir. ${ }^{21}$ Sahabe döneminin kadın müçtehitlerinden olan Ümmü Seleme'nin evinde büyümüş olması ona hem peygamber hanesi terbiyesi alma imkanı sunmuş hem de ilim yolunu açmış olmalıdır. Bununla birlikte sahabe nesli içerisinde yetişerek birçok sahabi ile görüşmüş olması da ona müstesna bir konum kazandırmıştır. İşte bu konumundan dolayı muhalefet ettiği yöneticilerin şerrinden korunmuş olabilir. Yani dönemin yöneticilerinin, bu müstesna konumundan dolayı ona saygı duyarak anlayış gösterdikleri söylenebilir.

Hasan Basrî, devrinin en saygın âlimlerinden birisiydi. Fıkıh, tefsir ve hadiste otorite idi. Sadece ilim ehli nezdinde değil, vaaz ve irşada önem veren zahid bir âlim olarak halk nezdinde hatta yönetici kesimi içerisinde de saygın bir konuma sahipti.22 İşte bu saygın konuma sahip bir âlim olması da Hasan Basrî'yi onların şerrinden koruyan bir kalkan olduğu düşünülebilir.

Hasan Basrî, her ne kadar bir muhalif idiyse de siyasi bir muhalif değildi. Bir âlim olarak, muhalefetini konumuna uygun bir

20 Fahreddin Razi, Muhassalu Efkari'l-Mütekaddimin ve'l-Müteahhirin mitne'l-Ulemai ve'l-Hükemai ve'l-Mütekellimin, Mektebetü'l-Külliyyati'l-Ezheriyye, Kahire, tsz., s. 240.

21 İbnu'l-Cevzî, Adab-u Hasanu'l-Basrî, s. 23.

22 Abdullah Aydınlı, "Hasan Basrî, Hayatı ve Hadis İlmindeki Yeri", Atatürk Üniveritesi İlahiyat Fakültesi Dergisi, 1988/8, ss. 91-110. 
davranış biçimiyle sürdürmekteydi. Dolayısyla ılımlı bir muhalif olduğu değerlendirmesi yapılarak bu sebepten kendisine anlayış gösterildiği de söylenebilir. Hatta mevaliden olması hasebiyle muhalefetinin önemsenmemiş olabileceği düşünülebilir, benzeri başka mülahazalar da ileri sürülebilir. Hasan Basrî́nin biyografisi incelendiğinde biyografisinin yukarıda sayılan bütün unsurları ihtiva ettiği ve bu hususların muhalefet ettiği yönetimin şerrinden onu korumak için yeterli olduğu söylenebilir. Ne var ki çekinmeden sahabe kanı döken, iktidar için her şeyi yapmaya hazır bir yönetim geleneğinin göstermiş olduğu bu hoş görü yine de fazla görünmektedir. O halde başka bir neden olmalıdır.

Doğrusu Hasan Basrî üzerine bir inceleme, onun bir başka müstesna yönünü işaret etmektedir. O da Hasan Basrî'nin âlim kimliği yanında zahid bir şahsiyet olması ve muhalefet ederken bunu her hangi bir dünyevî çıkar için yapmadığının ayan beyan olmasıdır. Öyle görünüyor ki o, bir taraftan dünya hayatında ilim tedrisi ve irşad ile saygın bir cehd sarf ederken, diğer taraftan yüzü ahirete dönük bir Allah dostu olarak, bir âlimin Allah indindeki sorumluluğunu yerine getirmek ve yaptıklarıyla Allah'ın rızasını kazanmak için muhalefet yapmaktaydı. Onun dünyasını şu sözleri açılamaktadir:

Kendisine en çok hayret ettiğim insan, dünya sevgisini büyük günah saymayan kişidir. Allah'a yemin ederim ki dünya sevgisinden daha büyük günah yoktur. Büyük günahlar ondan doğmamış mıdır? Putlara ibadet etmenin ve Allah'a isyan etmenin de sebebi dünya sevgisinden başkası mıdır?23

Öyle ki muhalefet ettiği kimseler dahi bu duruşu yanında muhalefet ettiği konulardaki haklılığı karşısında ona kin besleyemiyorlardı. Onun özü sözü bir, hiç bir art niyet emaresi olmaksızın sırf âlimin sorumluluğu, ümmetin ıslahı ve selameti için çabalamasının, bunu da Allah'ın rizasını tahsil etme gibi uhrevi bir gayeye matuf olarak yapmasının şiddetli muhalefetine rağmen kendisini hedef olmaktan çıkardığı söylenebilir. Nitekim bir gün Haccac, Vasıt'ta yaptırdığı bir sarayını Hasan Basrî’nin gelip görmesini istemesi üzerine gelişen olaylar bunu açıkça ortaya koymaktadır. Hasan Basrî de gelip sarayı gördükten sonra Haccac'ı kınamış ve sarf ettiği sözlerini, “Ey mağrur ve fasıkların en fasığı olan kişi! Yaptığın sarayı görmüş

23 İbnu'l-Cevzî, Adab-u Hasanu'l-Basrî, ss. 66. 
olduk. Ama gördük de ne oldu? Gök ehli senden nefret etti. Yeryüzündekiler sana lanet okudu. Şu fani dünyaya kapılarak saraylar inşa ettin. Fakat beka yurdunu harap ettin," şeklinde bitirmişti. Bu sözleri duyan Haccac, Hasan Basrî'ye öfkelenerek onu huzuruna aldırıp kendisi hakkında söylediklerinin hesabını sorunca da, söylediği o sözleriyle vehmettiği şeyleri kast etmediğini söyledikten sonra şöyle demişti: "Şimdi iki seçenek de senin elindedir. İster beni affedersin, ister cezalandırırsın. Kendine hangisini daha uygun görüyorsan onu yap. Fakat ne yapacaksan yalnız Allah'a dayanarak yap. Zira Allah bize yeter; o ne güzel vekildir." Bunun üzerine Haccac ondan utanmış, özür dileyerek ona izzet ve ikramda bulunmuştu. ${ }^{24} \mathrm{Bu}$ hadise yanında, yukarıda geçtiği gibi, gerek halife Abdu'l-Melik b. Mervan, gerekse de Ömer b. Abdulaziz'in Hasan Basrî hakkındaki ifade tarzları, onun ne denli saygın bir konuma sahip olduğunu göstermektedir. Bir başka ifadeyle "samimiyetine ve ilmine inanılan bir şahsiyet sahibi olması," 25 ona düşmanlık edilmesine engel olmuş ve ümmetin salahı için sürdürdüğü muhalefetinin, saygı duyulan faydalı bir muhalefet olmasını sağlamıştır.

\section{Sonuç}

İşte muhalif duruşuna rağmen dost düşman herkesin nezdinde böyle saygın bir konumda olmasının arkasındaki en büyük neden, onun, zühd denince akla ilk gelen şahsiyet olarak hatırlanmasını sağlayan dünya ve ahiret arasında kurduğu dengede temayüz eden şahsiyetidir. Nitekim bu şahsiyetli ve zahidane duruşu, diğer din mensuplarını dahi derinden etkilemiştir. Mesela bir Sabiî olan Sabit ibn Kurra şöyle demiştir: "Şu Arap milletine sadece üç kişiden dolayı hased ederim. Çünkü kadınlar artık onların benzerini doğuramazlar. Onların ilki Ömer İbn Hattab; ikincisi Hasan el-Basrî. Bu zat ilim, takva, zühd, vera, iffet, rikkat, kulluk, tenezzüh, fıkıh ve marifet yönünden parlak yıldızlardandır. Üçüncüsü ise, Ebû Osman elCâhız'dır."26

24 İbnu'l-Cevzî, Adab-u Hasanu'l-Basrî, ss. 107-108.

25 Mevlüt Uyanık, “İslam Toplumunun Oluşum Sürecinde 'Muhalefet' Kavramı, Hasan Basrî örneği", III. Kur'an Haftası, Kur'an Sempozyumu, 13-19 Ocak, Ankara, 1998, s, 111.

26 Hasan Basrî́nin biyografisi için bk. Abdullah Aydınlı, "Hasan Basrî, Hayatı ve Hadis İlmindeki Yeri", Atatürk Üniveritesi İlahiyat Fakültesi Dergisi, sayı viii, 1988. 
Hasan Basrî, Hz. Ümmü Seleme üzerinden aldığı nebevi ahlak eğitimini, İslami ilimler alanında da geliştirerek İslam'ın erken dönem âlimleri arasında müstesna bir yer edinmiştir. Emevi iktidarına yönelttiği eleştiri ve muhalefetinin, siyasi ya da şahsi çıkarları adına değil sahip olduğu ilmin gereği olarak sergilenmiş bir tutum olduğu anlaşılmaktadır. Bu tür muhalefet tarzı "iyi olanı emredip kötü olandan sakındırmak" ilahi emrinin iktidarın yüzüne söyleyebilme durumunu ifade etmektedir. Hasan Basrî́ de kişisel ikbal ya da enaniyet duygularına dayanan bir muhalefet yerine, ümmetin birliği için her türlü kötülüğe muhalif duruşun müstesna örneğini görmekteyiz.

\section{Kaynakça}

Aydınlı, Abdullah. "Hasan Basrî, Hayatı ve Hadis İlmindeki Yeri”, Atatürk Üniveritesi İlahiyat Fakültesi Dergisi, sayı vı11, 1988.

“Hasan Basrî’nin Kader Hakkında Halife Abdülmelik Bin Mervan'a Mektubu", çev.: Lütfi Doğan, Yaşar Kutluay, Ankara Üniversitesi İlahiyat Fakültesi Dergisi, c. iii, sayı iii, 1954.

İbnu'l-Cevzî, Cemaleddin Ebu'l- Ferec. Adab-u Hasanu'l-Basrî, Beyrut, 2008. İbn Kuteybe, Ebu Abdullah Muhammed b. Müslim. el-Mearif, tahk., Servet Ukkas,e, Daru'l-Mearif, Misır, 1969.

İşcan, Mehmet Zeki. Ehl-i Sünnet'in Oluşumunda Öncü Şahsiyetler, Hasan Basrî ve Ebû Hanife Üzerine Bazı Mülahazalar, Komisyon, Tarihte ve Günümüzde Ehl-i Sünnet, İstanbul, 2006.

Razi, Fahreddin. Muhassalu Efkari'l-Mütekaddimin ve'l-Müteahirin mitne'lUlemai ve'l- Hükemai ve'l-Mütekellimin, Mektebetü'l-Külliyyati'l-Ezheriyye, Kahire, tsz.

Taberî, Ebu Ca'fer Muhammed b. Cerir. Tarihu'l-Ümem ve'l-Mülûk, Daru'lFikr, Beyrut, 1987, s. 196.

Tefsir-u Hasan Basrî, (Muhammed Abdurrahim neşri) Kahire, 1992.

Uyanık, Mevlüt. “İslam Toplumunun Oluşum Sürecinde 'Muhalefet' Kavramı”, Hasan Basrî Örneği, III. Kur'an Haftası, Kur'an Sempozyumu, 1319 Ocak, Ankara, 1998. 